ARCHIVO ESPAÑOL DE ARTE, LXXXVII, 347

JULIO-SEPTIEMBRE 2014, pp. 263-280

ISSN: 0004-0428, eISSN: 1988-8511

doi: $10.3989 /$ aearte.2014.17

\title{
LOS YUNTEROS DE EXTREMADURA (MARQUÉS DE VILLA-ALCÁZAR, 1936): UN ESLABONN RECUPERADO DEL DOCUMENTAL CINEMATOGRÁFICO DE LA SEGUNDA REPÚBLICA ${ }^{1}$
}

\author{
Pedro Poyato SÁnchez \\ Universidad de Córdoba
}

La reciente recuperación de Los yunteros de Extremadura, documental producido por el Instituto de Reforma Agraria en 1936, ha supuesto un paso más en la reconstrucción de la filmografía de la Segunda República, periodo crucial en la historia del documental del propaganda. Requerida por la Delegación de Propaganda en París, Los yunteros de Extremadura es, sin embargo, una película especialmente crítica con la República. El presente trabajo se ocupa de esta cuestión como también de la iconografía del filme y del interesante diálogo que este mantiene con Las Hurdes/ Tierra sin pan, de Luis Buñuel (1933/1936).

Palabras clave: Cine; República; Documental; Iconografía; Propaganda; Yunteros.

\section{LOS YUNTEROS DE EXTREMADURA (MARQUÉS DE VILLA-ALCÁZAR, 1936): A RECOVERED LINK OF DOCUMENTARY CINEMA FROM THE SECOND SPANISH REPUBLIC}

The recent recovery of Los yunteros de Extremadura (The Plowmen of Extremadura), a documentary produced by the Instituto de Reforma Agraria in 1936, is a step forward in the reconstruction of the filmography of the Second Spanish Republic, a crucial period in the history of the propaganda documentary. Requested by the Republican Propaganda Agency in Paris, Los yunteros de Extremadura was nevertheless especially critical of the Republican government. This study analyzes this question as well as the iconography of the film and its interesting dialogue with Bunuel's Las Hurdes/Land Without Bread (1933 / 1936).

Key words: Film; Republic; Documentary; Iconography; Propaganda; Yunteros (plowmen).

\footnotetext{
${ }^{1}$ Este trabajo ha sido elaborado en el marco del proyecto de investigación Estudio de la obra cinematográfica del Marqués de Villa Alcázar producida por el Ministerio de Agricultura del Programa de Estudios del Departamento de la Subdirección General de Análisis, Prospectiva y Coordinación del Ministerio de Agricultura, Alimentación y Medio Ambiente (referencia 00017.2012).
} 


\section{Recuperación e identificación del documental. Algunos datos sobre su realización}

En diciembre de 2012, Vladimir Magidov, profesor de la Universidad Estatal Rusa de Humanidades, hizo entrega al Centro Galego de Artes de Imaxe (CGAI) de un DVD que, con el genérico The Documentary Film-chronicle of Spain (1936-1939), contenía 36 minutos de imágenes procedentes del Archivo del Estado Ruso de Cine Documental y Fotografía de Krasnogorsk. El DVD incluía 16 minutos de imágenes, en tres bloques, de la Galicia de Carlos Velo, sin créditos; un metraje parcial sobre Valencia; y Los yunteros de Extremadura, documental producido por el Instituto de Reforma Agraria de la República, sin los créditos finales. Los historiadores del cine español se interesaron rápidamente, dado el prestigio de Velo y la importancia de Galicia, que recibió el Diploma de Oro en la Exposición Internacional de París, por este filme -que incluía las imágenes referidas al trabajo de los marineros, no disponibles en la única versión conservada hasta entonces- sin prestar demasiada atención a Los yunteros de Extremadura, película finalmente recuperada por el Ministerio de Agricultura.

Aunque solo existen hipótesis para explicar cómo estas películas acabaron en el archivo moscovita, lo más probable, sobre todo si se tiene en cuenta que todas ellas fueron requeridas por la Delegación de Propaganda en París, es que, una vez concluida la Guerra Civil, fueran depositadas en la Embajada rusa de la capital francesa y posteriormente enviadas desde allí a Moscú. Sea como sea, la recuperación de este patrimonio ha supuesto un paso importante en la reconstrucción de la filmografía de la II República Española, periodo crucial en la historia del documental cinematográfico por cuanto, además de trabarse en él vanguardia y cultura de masas, marca el nacimiento del documental de propaganda.

Fernando Camarero, autor del Catálogo de Documentales Cinematográficos del Ministerio de Agricultura ${ }^{2}$, identificó enseguida Los yunteros de Extremadura como un filme dirigido por Francisco González de la Riva, Marqués de Villa-Alcázar; atribución que se ha visto confirmada con la aparición de una documentación que ha permitido averiguar también las fechas de realización del filme y algunas de las incidencias que tuvieron lugar durante su rodaje. Se trata de cuatro documentos ${ }^{3}$ que son otras tantas cartas intercambiadas entre distintos cargos del Ministerio de Agricultura, entre ellos el propio González de la Riva, a la sazón Jefe de Sección de Publicidad y Publicaciones del Instituto de Reforma Agraria de la Segunda República. En la primera de las cartas, de fecha 11 de marzo de 1936, el director del IRA pone en conocimiento del Secretario General que González de la Riva y otros cuatro funcionarios del Ministerio se trasladan a Cáceres en comisión de servicio. En la segunda, fechada el 4 de mayo de 1936, el también director del IRA informa ahora del traslado, en comisión de servicio, de González de la Riva a las provincias de Cáceres y Badajoz, acompañado del chófer y de un electricista. En la tercera carta, de fecha 5 de mayo de 1936, el propio Francisco González de la Riva comunica al Secretario General del IRA que, en cumplimiento de la orden del director, ese mismo día sale para Cáceres para "la toma de escenas para una película sobre yunteros". Finalmente, en la cuarta carta, fechada el 12 de mayo de 1936, González de la Riva notifica lo siguiente al Sr. Secretario General del IRA:

Habiendo impresionado aquellas escenas de la película sobre YUNTEROS que tenían que ser hechas en los alrededores de Cáceres, y teniendo que luchar con una absoluta falta de luz y sol brillante, indispensables para hacer películas brillantes y de buen valor fotográfico, y teniendo por delante dos días de fiesta, y un número indeterminado de días nubosos [...] he regresado a Madrid

\footnotetext{
2 Camarero, 2010.

3 Archivo del Instituto de Reforma Agraria, Ministerio de Agricultura, Madrid, Estado, expediente personal del Marqués de Villa-Alcázar.
} 
con objeto de hacer revelar las escenas ya tomadas, empezar el trabajo de montaje de la película y esperar a que se estabilice el buen tiempo para regresar a Navalmoral de la Mata a tomar las escenas que aun faltan para terminar la película.

A la vista de esta documentación, se infiere que el viaje de González de la Riva a Extremadura en marzo de 1936 estaba muy probablemente destinado a obtener información y buscar localizaciones para la realización del filme, algo en lo que redunda el hecho de que se hiciera acompañar de cuatro asesores, un Ingeniero Agrónomo, dos Ayudantes de Montes y un Perito Agrícola del Estado, todos ellos también funcionarios del Ministerio. Recabada ya la información, González de la Riva comienza, según sus propias palabras, la filmación sobre los yunteros la semana del 5 al 12 de mayo de 1936, y, aprovechando el parón del rodaje motivado por el mal tiempo, inicia el montaje inmediatamente después. No existe, sin embargo, documentación sobre las fechas en las que prosiguió el rodaje del filme, y que bien pudiera no haberse llevado a efecto, sobre todo si se tiene en cuenta la carencia de material rodado que puede percibirse en determinados pasajes de la película, especialmente en su parte final.

\section{El problema yuntero en la primavera de 1936}

¿Qué movió al Ministerio de Agricultura, al Instituto de Reforma Agraria, concretamente a su Jefe de Publicidad, a preparar, justo en marzo de 1936, la realización de una película sobre los yunteros de Extremadura? ¿Qué interesaba de este grupo campesino tan popular en esa época? ¿Cuál era la situación de los yunteros extremeños cuando González de la Riva hace la película? Comencemos por este último asunto, cuya respuesta exige hacer un poco de historia ${ }^{4}$. Durante los primeros meses de 1936, el paro agrícola en España, al que contribuyó un invierno de intensas lluvias en todo el país, había aumentado más de un veinte por ciento. Esta casi insostenible situación llevaría, a partir de marzo, a una oleada de ocupación de fincas en Cenicientos (Madrid) que se propagó rápidamente por otras provincias. Los denodados esfuerzos del gobierno de Azaña para detener esta expansión, y sobre todo para que no llegara a Extremadura, donde los yunteros se habían convertido en el grupo campesino más politizado de España, se concretaron, a instancias de Mariano Ruiz Funes, Ministro de Agricultura, en un decreto de 5 de marzo de 1936 en el que se invitaba a los yunteros expulsados en 1935 a solicitar la devolución de sus tierras, ordenándose al IRA la resolución de las solicitudes en el plazo máximo de un mes; plazo que sería luego acortado al prometer el ministro, en un viaje relámpago por Badajoz y Cáceres, el asentamiento de cuarenta mil yunteros en una semana.

Sin embargo, dado que el 20 de marzo sólo se habían asentado 3000 yunteros, la Federación Española de Trabajadores de la Tierra (FETT) $)^{5}$ ordenó a la Federación de Badajoz que lanzase un asalto masivo a las fincas en toda la provincia; asalto que se materializaría a las cinco de la madrugada del 25 de marzo de 1936, cuando unos sesenta mil campesinos se pusieron en marcha para ocupar alrededor de tres mil fincas previamente seleccionadas al grito de "Viva la República". El gobierno, que en un primer momento había optado por enviar a las tropas, accedió finalmente, tres días después, a legalizar las ocupaciones. De este modo, durante los cinco meses que van de marzo a julio - período que coincide justo con el de la preparación y realización del filme de González de la Riva- aproximadamente una tercera parte de la población masculina campe-

\footnotetext{
4 Para la elaboración de este apartado nos hemos basado en MALEFAKIS, 1976: 418-441; EsPinOSA MAestre, 2007; y RIESCO Roche, 2009: 41-64.

5 Antigua Federación Nacional de Trabajadores de la Tierra, y que, tras la constitución del gobierno del Frente Popular, en febrero de 1936, pasó a llamarse así.
}

Arch. esp. arte, LXXXVII, 347, JULIO-SEPTIEMBRE 2014, 263-280

ISSN: 0004-0428, eISSN: 1988-8511, doi: 10.3989/aearte.2014.17 
sina de Extremadura recibió algunas tierras: en Cáceres, por ejemplo, lugar donde se realiza Los yunteros de Extremadura, los campesinos asentados fueron más de treinta mil, y casi ciento catorce mil las hectáreas ocupadas.

Pues bien, Los yunteros de Extremadura en absoluto va a interesarse por estas ocupaciones y asentamientos de los yunteros, temas candentes, como acabamos de ver, durante los procesos de gestación y realización del filme, y que son sin embargo orillados en favor de otros -y comenzaríamos a responder así las otras preguntas antes planteadas- como las miserables condiciones de vida de los yunteros, en especial las paupérrimas viviendas que habitan; temas que sin duda eran de más conveniencia para los intereses del filme, o más exactamente de su realizador, como trataremos de justificar en los epígrafes que siguen.

\section{Contexto en el que surge el documental}

A diferencia del resto de documentales de la vasta producción de González de la Riva, tanto de los años 30 como de los posteriores a la Guerra Civil, dedicados bien a las labores agrícolas, como la siembra, los abonos o los cultivos, bien a los productos del campo, como el trigo, el tabaco, el vino o las naranjas y pomelos, o bien a las mejoras de la producción y aprovechamiento de estos y otros productos, Los yunteros de Extremadura se ocupa, como su título indica, de un grupo humano, los yunteros extremeños. Esto lleva al filme a inscribirse en una tradición del documental etnográfico que, nacida ya con los hermanos Lumière y sus operadores nómadas, se consolidaría precisamente en los años treinta, donde muchos de estos documentales acusaban rasgos sensacionalistas que trataban de apelar a una respuesta emocional por parte del espectador. Tal es el contexto cinematográfico en el que surge el documental del Marqués de Villa-Alcázar, emparentado en este sentido a películas como La Zone (Georges Lacombe, 1928), cuyas imágenes exploran los tugurios que rodean el cinturón de París, en la zona de Clignancourt, mostrando el trabajo de los traperos y a los mendigos escarbando entre los escombros. O como La sal de Svanetia (Sol Svanetii, Mijail Kalatozov, 1930), que describe la vida pobre y difícil de una población aislada en las montañas del Cáucaso, víctima sobre todo de su angustiosa carencia de sal. O como Prix et profits/ La Pomme de terre (Marc Allégret, 1931), una producción didáctica acerca de la explotación de los campesinos franceses ${ }^{6}$. Pero sin duda el representante mayor de esta corriente documental es Las Hurdes/ Tierra sin pan (Buñuel, 1933/ 1936), película con la que Los yunteros de Extremadura, además de compartir este enraizamiento común, va a mantener diálogos tan ricos como interesantes, como se verá. Al igual que en el filme de Buñuel, en el de González de la Riva todo está reconstruido, elaborado, y nos atreveríamos a decir que interpretado para la ocasión, con vistas sobre todo a la construcción de un discurso que despierte en el espectador una compasión hacia las tragedias de sus personajes, apremiándole así a una acción inmediata.

Nos ocupamos a continuación de estas consideraciones anteriores a partir de un exhaustivo análisis de Los yunteros de Extremadura, análisis que segmentaremos diacrónicamente en distintos apartados caracterizados cada uno de ellos por una relativa unidad temática: el que sirve de introducción referido a la distribución de la riqueza de la tierra y a la ciudad como hábitat de los propietarios de las fincas; el yuntero y sus herramientas de trabajo; la resistencia de la tierra; el hogar de las familias yunteras; la causa de tanta miseria; y el destino final del yuntero. A lo largo del análisis, dedicaremos especial atención a la iconografía trabajada por el fílme, como

${ }^{6}$ Román Gubern se ha ocupado ampliamente de esta corriente del documental cinematográfico de los años treinta en: GUBERn, HAMMOND, 2009: 170-172. 
también a la relación que este mantiene, además de con Las Hurdes/ Tierra sin pan, presente por muchos motivos en el horizonte de Los yunteros de Extremadura, como con Yuntero extremeño, texto literario publicado en el Boletín del IRA, en mayo de 1936, y que es sin duda una de las fuentes del documental de González de la Riva.

\section{Arranque del documental. El yuntero y sus herramientas de trabajo}

Los títulos de crédito nos sitúan ante una película de divulgación del Instituto de Reforma Agraria, a cuya autoría se asigna guión, fotografía y montaje, pero sin que se haga alusión alguna a la identidad de la voz locutoria. El fragmento primero sirve de introducción al filme y detalla, ayudándose de ilustraciones gráficas animadas, la distribución de la riqueza agraria en cuatro partidas distintas, entre ellas las de mejoras de la finca, jornales de quienes labran las tierras -los yunteros, en este caso-, y rentas que se van adonde vive el propietario de las tierras. Advierte la voz narradora: "cuando el propietario vive lejos, el único dinero que queda en la región es el que se gasta en mejoras y jornales, y si éstos escasean, los moradores de la misma llevarán una vida miserable".

Y esto es justo lo que sucede, según prosigue el filme, en el caso de las fincas de Extremadura: como los propietarios viven lejos, en las grandes ciudades, y los jornales escasean, los campesinos llevan una vida miserable. Sirve este razonamiento para la introducción de un motivo, la vida miserable, que Los yunteros va a compartir con Las Hurdes/ Tierra sin pan: ahora bien, si en el documental de Buñuel la miseria es motivo de denuncia y, también, plástico -sus imágenes hacen poesía visual con ella-, en el de González de la Riva va a serlo, sobre todo, de denuncia. He aquí una primera y sustancial diferencia entre un filme y otro que va a traducirse, como tendremos ocasión de constatar, en unas cualidades distintas de las imágenes respectivas.

El segmento fílmico siguiente introduce el campo extremeño, las ovejas pastando en las dehesas, del que la voz narradora advierte que el importe de sus productos se suele gastar lejos, en las grandes ciudades, pues es en ellas -fácil es inferirlo- donde habitan los propietarios de las fincas. Con este pretexto, la ciudad de Madrid protagoniza las siguientes imágenes, así el torbellino de su vida agitada, el tráfico intenso, la muchedumbre acudiendo a los toros. Pero también la arquitectura de sus monumentos; las fachadas de los rascacielos y de las altas torres, mostradas mediante contrapicados oblicuos que acentúan el mareo de la altura; y finalmente las terrazas de los bares pobladas todas ellas de abundante gentío. El narrador, por su parte, se dedica a comentar brevemente algunas de las imágenes, así la belleza de los monumentos o la osadía de las altas torres "que tratan de estirarse hasta las nubes", finalizando su discurso con una alusión a la vida en la ciudad; una vida, concluye, "que deja tan poco tiempo libre para pensar en las tribulaciones del pobre campesino, del pobre hombre que con dos míseros borriquillos y un arado primitivo constituyen el típico yuntero extremeño".

La ciudad moderna, con sus edificios y ritmos vertiginosos, protagoniza, pues, las imágenes del segmento anterior, en sintonía temática -que no formal- con lo establecido la década precedente por las llamadas sinfonías urbanas cinematográficas; imágenes que se constituyen a su vez en el comienzo festivo y hedonista de una estructura muy contrastada que encuentra su continuación en las miserables tierras extremeñas, allí donde habita el pobre yuntero ${ }^{7}$. Luego de caracterizarlo implícitamente como olvidado, el narrador ha definido ejemplarmente la estampa de este yuntero, que vemos visualizada en la imagen: forzando en efecto un acusado contraste con la

\footnotetext{
${ }^{7}$ Estructura que, invirtiendo el itinerario de Alfonso XIII en su viaje a la región, había sido ya elegida por Las Hurdes, que comienza en la fiesta de La Alberca para descender luego hasta las miserables Hurdes Altas. En GuBERN, HAMMOND, 2009: 183.
}

Arch. esp. arte, LXXXVII, 347, JULIO-SEPTIEMBRE 2014, 263-280

ISSN: 0004-0428, eISSN: 1988-8511, doi: 10.3989/aearte.2014.17 
anterior de la gente de la ciudad abarrotando las terrazas de los bares, esta otra imagen resulta protagonizada por el pobre campesino y los dos viejos borricos uncidos a la yunta (fig. 1). Comienza así una parte del filme que muy probablemente pueda tener su origen en el texto Yuntero extremeño de Felipe de la Fuente, un aguafuerte, en sus mismas palabras, sobre el yuntero extremeño, su vida y ambiente en que se desenvuelve, que fue publicado en el Boletín del Instituto de Reforma Agraria del Ministerio de Agricultura, en mayo de $1936^{8}$. Sea como sea, la comparación entre texto fílmico y literario está justificada por cuanto se trata de obras patrocinadas ambas por la misma Institución, el Instituto de Reforma Agraria, y realizadas justo en las mismas fechas, mayo de 1936; comparación que por lo demás va a permitirnos constatar hasta qué punto González de la Riva acentúa, estirándolas hasta la casi deformación, las aristas más trágicas del texto de De la Fuente.

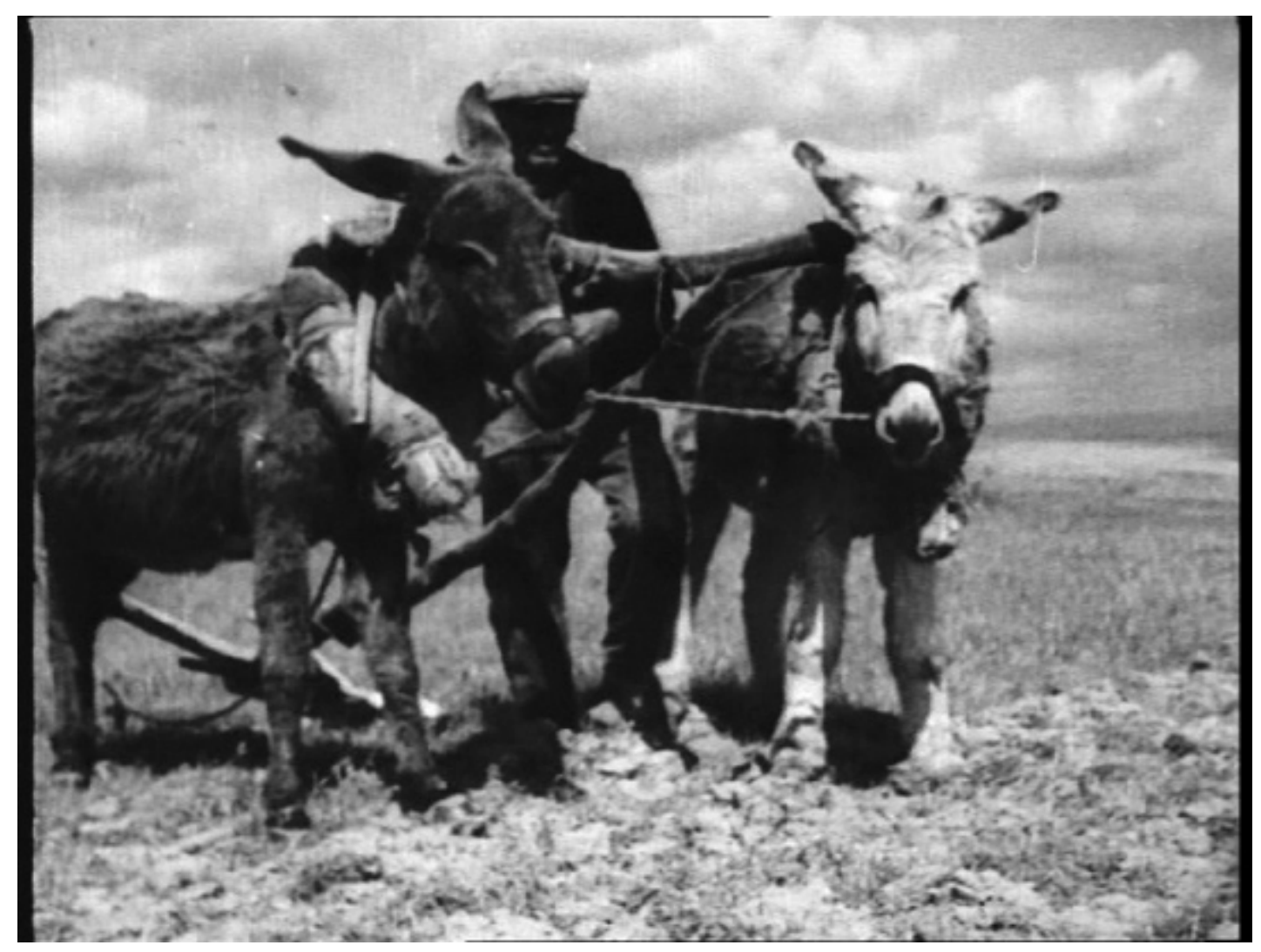

Fig. 1. Los yunteros de Extremadura (1936): estampa del yuntero.

Precisamente, esa primera estampa del campesino extremeño uncido a su yunta que vemos en el documental es la misma que ilustra el aguafuerte literario; imagen que se constituye en el inicio de la notable iconografía del yuntero que el filme va a trabajar. A partir de aquí, el docu-

8 De la Fuente, 1936: 475-478. 
mental presenta a un gran número de yunteros en la mañana, a la salida del pueblo, camino del tajo. El aire alegre que desprenden las imágenes, donde vemos a los yunteros acompañados de las mujeres, de los niños y hasta de los perros, subidos todos ellos a lomos de los burros, se contrapone a las palabras del narrador, quien, refiriéndose a los burros, recuerda el día que les espera, "tirando del arado". A la zaga de la procesión, puede observarse un burro joven que no quiere quedarse atrás: el trotecillo alegre emprendido por el animal sintoniza con la alegría del conjunto, pero de nuevo irrumpe la voz narradora para tachar al animalillo de "aprendiz de yunta". Puede adivinarse ya aquí el patrón ideológico en torno al que va a modelarse el discurso del narrador, aunque para ello haya de apartarse, como es el caso, de lo mostrado por las imágenes. Volveremos sobre este mismo asunto más adelante.

Progresivamente, con la desaparición de las mujeres, los niños, los perros y hasta del aprendiz de yunta, las imágenes acaban centrándose exclusivamente en los yunteros y sus escuálidos jamelgos para atender a los momentos de la comida de unos y otros: en primer lugar, la de quienes "arando pasan el día, de sol a sol, sin más recreo que la frugal comida: un guisadito o un trozo de pan seco, un trago, generalmente de agua, y como gran lujo, un cigarrillo", palabras que oímos sobre planos amplios de unos cuantos yunteros (fig. 2) que se alternan con otros más cercanos destinados a capturar sus rostros ásperos (fig. 3), "del color de la tierra, curtidos por el sol abrasador", concreta el narrador; planos todos ellos destinados, como aquel otro comentado más arriba (fig. 1), a elaborar una iconografía cinematográfica del yuntero. En segundo lugar, las imágenes atienden a la yunta para mostrar a los dos pollinos negros, viejos, "sin ganas de comer de tan rendidos como están", matiza el narrador, que concluye: "aguardando filosóficamente a que acabe el rato de descanso".

Este tiempo dedicado a la comida es recogido igualmente en el texto de De la Fuente, que lo relata así: "No le robará [el yuntero] más minutos [al horario de su faena] que los estrictamente indispensables para que su pareja de bestias trinque en el pasto, en tanto él saborea su mísero

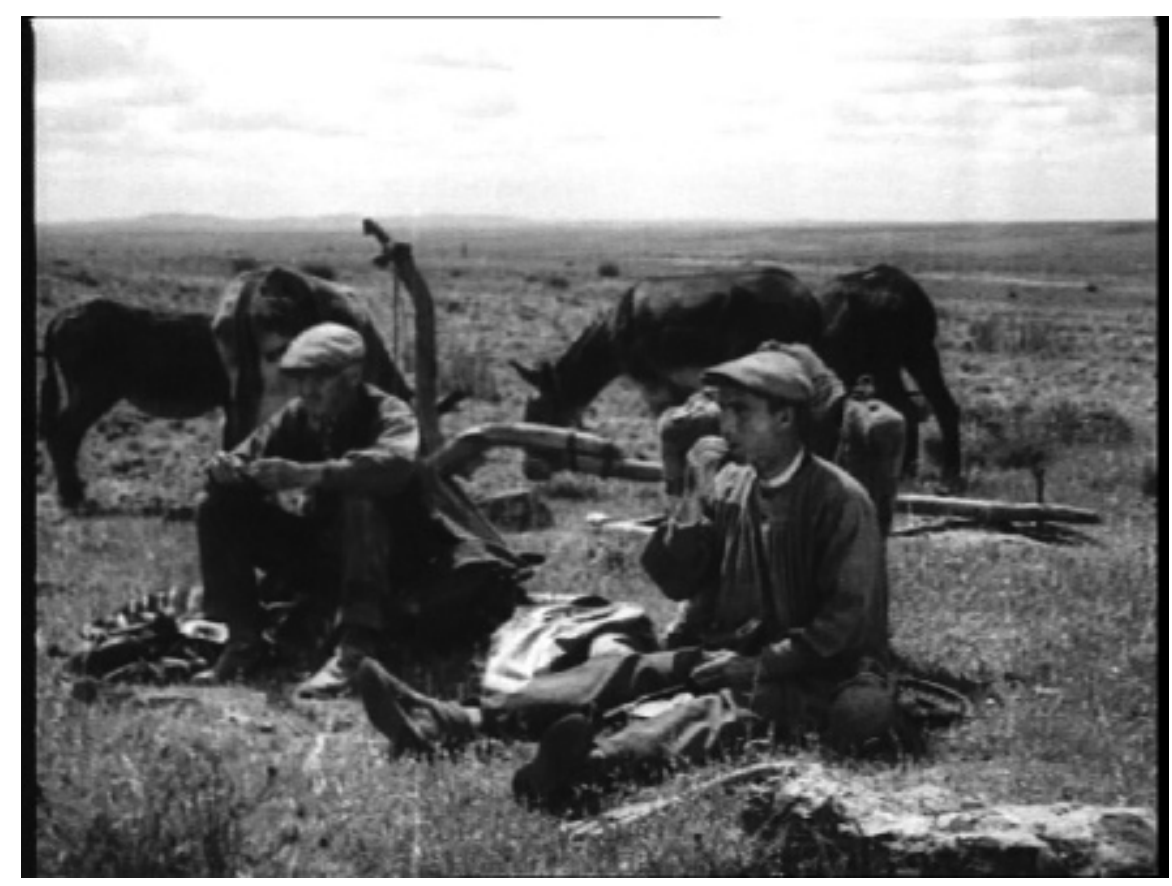

Fig. 2. Los yunteros de Extremadura (1936): el mísero yantar. 


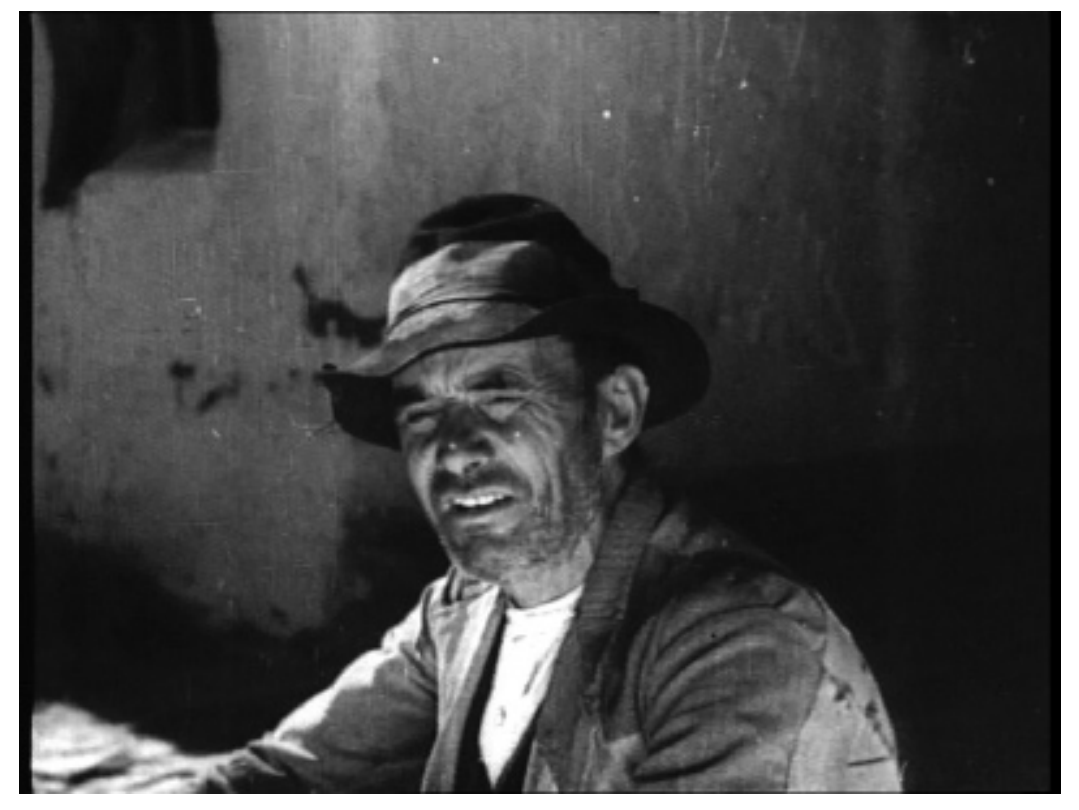

Fig. 3. Los yunteros de Extremadura (1936): rostro del color de la tierra.

yantar"9. Constatamos cómo, además de subrayar este mísero yantar del yuntero, detallando sus ingredientes, el filme carga de nuevo las tintas sobre los burros, que, en vez de trincar en el pasto, aparecen transidos por el cansancio, sin fuerzas ni para comer, sólo aguardando, "filosóficamente", apunta con ironía el narrador, a que acabe el poco tiempo robado a la faena ${ }^{10}$. Mas también la geografía del rostro del yuntero, referida por el filme en este segmento de la comida, es reseñada en Yuntero extremeño, en este caso en las líneas que le sirven de apertura: "Tez tostada por el sol calcinante de Extremadura, confundiendo el color de sus hombres con el de la tierra parda", confusión rostro-tierra que, como hemos visto, sirve también de referencia al narrador en su descripción de la iconografía del yuntero declinada por el filme.

\section{La resistencia de la tierra}

El segmento fílmico siguiente muestra al yuntero trabajando a duras penas, con el burro tirando de un rudimentario arado que apenas puede romper la áspera y seca capa de tierra: los planos generales donde se aprecia el concienzudo esfuerzo del viejo burro, se suceden con planos detalle de la tierra resistiéndose a ser horadada por el filo cortante del arado. Serguei M. Eisenstein es aquí el intertexto, concretamente las imágenes más crueles de Lo viejo y lo nuevo (Staroye i novoye, 1929), aquellas que muestran a la campesina Marfa unciendo a su arado una pequeña y vieja vaca. Pero el pasaje anterior encuentra también otro intertexto en Yuntero extremeño

9 De la Fuente, 1936: 477.

${ }^{10}$ La ideología que gobierna el discurso construido por el narrador aflora de nuevo en estas imágenes, mucho más cuando comprobamos que como fondo de los planos anteriores de los yunteros comiendo, aparecían los burros pastando (F2); fondo que, ignorado entonces por la palabra del narrador, es ahora traído a primer término en la forma que acabamos de ver. 
allí donde este se refiere al "sino" de la yunta: "Arrastrar una horquilla de madera, con ramas desiguales, que en su unión llevan un pedazo de hierro aguzado, con el que rompen la tierra; definición rudimentaria del más primitivo de los arados"11. Puede apreciarse cómo, una vez más, el documental fuerza el texto literario, en este caso llamando la atención sobre la oposición de una tierra que apenas se deja romper por el tosco arado.

Los yunteros de Extremadura abre en lo que sigue una suerte de paréntesis para proponer una fácil solución a estas penurias del yuntero. Dice el narrador: "Hubiese bastado lo que cuesta un juego de neumáticos para que el yuntero hubiera podido disponer de una yunta fuerte y de una buena vertedera, una vertedera que vuelque la tierra como vuelca un automóvil en una curva mal tomada, haciendo con ello producir más al suelo y dándole ocasión de labrar con el cariño y orgullo que proporciona la labor bien hecha". Destaca en este discurso, además de su remate, modelo que anticipa muchos finales de las películas del Marqués de Villa Alcázar de los años cuarenta, donde el campesino, disponiendo ya de las herramientas adecuadas, se entrega orgulloso a una labor bien hecha que va a redundar en la prosperidad de la patria, la presencia del automóvil como motivo de comparación, tanto por lo que se refiere al coste económico (con una mínima parte de su importe - lo que vale un simple juego de neumáticos- se compra una buena vertedera), como a su facilidad para volcar en la curva (como la tierra cuando es horadada por esa misma vertedera). Motivo de comparación que no escapa a las imágenes, al mostrar estas, primero, un juego de engranaje de ruedas de automóvil en pleno giro (fig. 4), según una compo-

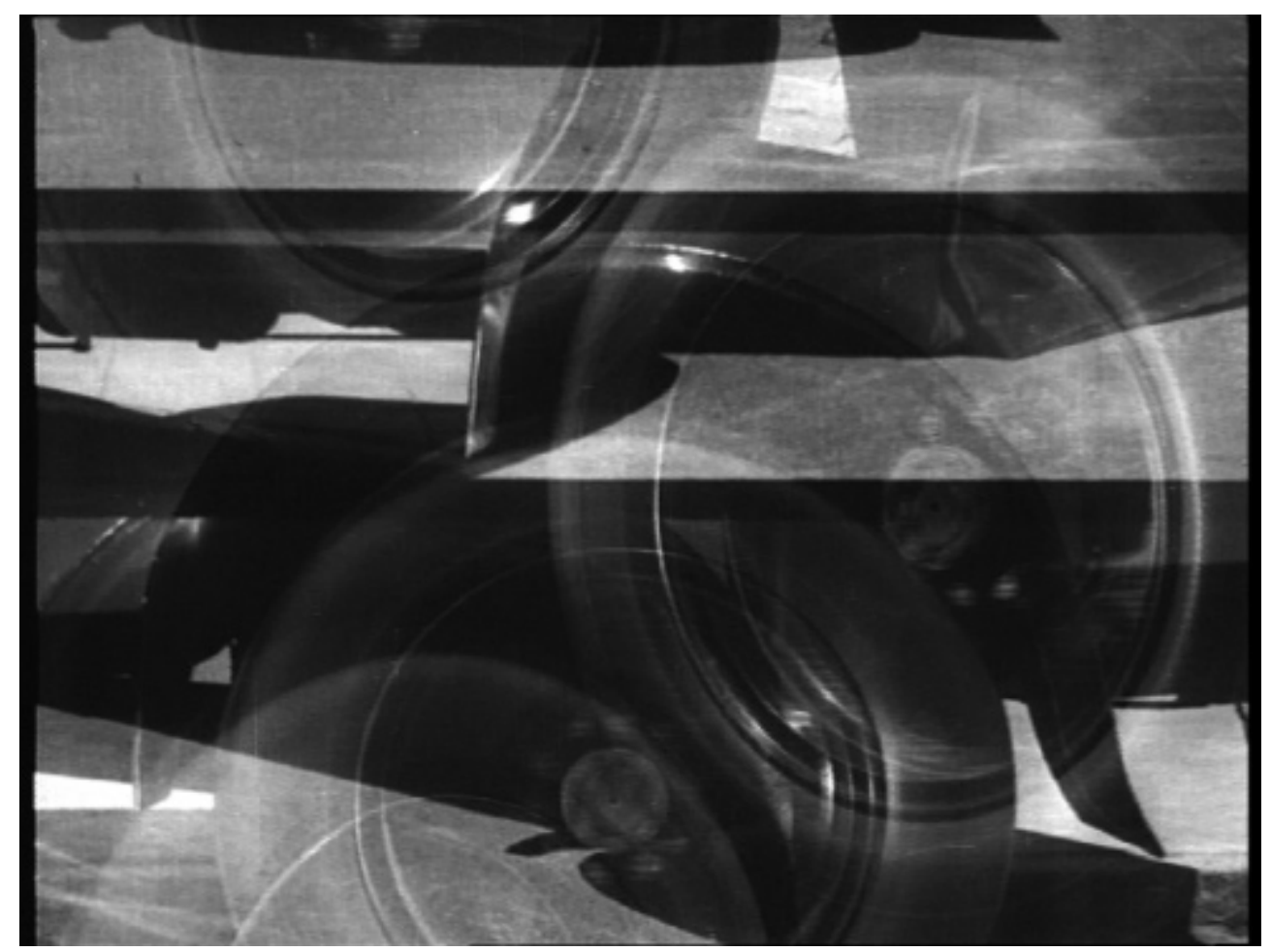

Fig. 4. Los yunteros de Extremadura (1936): maquinismo.

11 De la Fuente, 1936: 476.

Arch. esp. arte, LXXXVII, 347, JULIO-SEPTIEMBRE 2014, 263-280

ISSN: 0004-0428, eISSN: 1988-8511, doi: 10.3989/aearte.2014.17 
sición maquinista bien próxima a las abstracciones trabajadas por las vanguardias cinematográficas de los años veinte; y luego, un coche volcando al tomar la curva, como la vertedera vuelca la tierra. El filme enfrenta así la escasez que preside las condiciones de trabajo del yuntero, en el campo, con el derroche propio de la vida urbana, representada en este caso por el automóvil, objeto de consumo caro y peligroso.

En Yuntero extremeño, De la Fuente se refiere igualmente a la dicotomía campo/ ciudad en los siguientes términos: "Hoy se puso de moda en la ciudad su antítesis [del campo]: él es todo trabajo y nobles afanes, en tanto ella representa holgazanes y desvío"12. Si en el documental los términos asociados al par campo/ ciudad son escasez vs. derroche, en el texto literario lo son trabajo y nobles afanes vs. holgazanes y desvío. Y en la misma línea del documental, el texto de De la Fuente apunta cómo la solución del yuntero pasa por el encuentro entre el campo y la ciudad: "De todas formas, si el campo y la ciudad han de unirse en un anhelo de mejora de aquél y redención de ella, el papel del yuntero seguirá subiendo. Son y representan la futura redención del campo" ${ }^{3}$. Sin embargo, el documental de González de la Riva, prosiguiendo su línea ideológica, se encarga de apuntar en seguida que ese encuentro ciudad-campo del que surgen la yunta fuerte y la buena vertedera que acabamos de ver en las imágenes, era sólo una ilusión, una fantasía, retornando por ello las imágenes siguientes a la más dura realidad; realidad que se traduce, cuando llega la siega, como no olvida advertir el narrador, en "espigas poco granadas y en haces de mies escasos y con maleza". Dignos de mención son los planos que acompañan estas palabras, planos de las espigas mecidas por el viento que, aun cuando con poco grano y con apreciables claros entre ellas (fig. 5), son de una belleza plástica extraordinaria, al igual que los de los segadores con los haces de mies (fig. 6). El documentalista empieza a componer así una iconografía de la siega que, inspirada en algunos filmes de esos mismos años, como Nobleza baturra (Florián Rey, 1935), llegará a su culminación plástica en películas posteriores, como

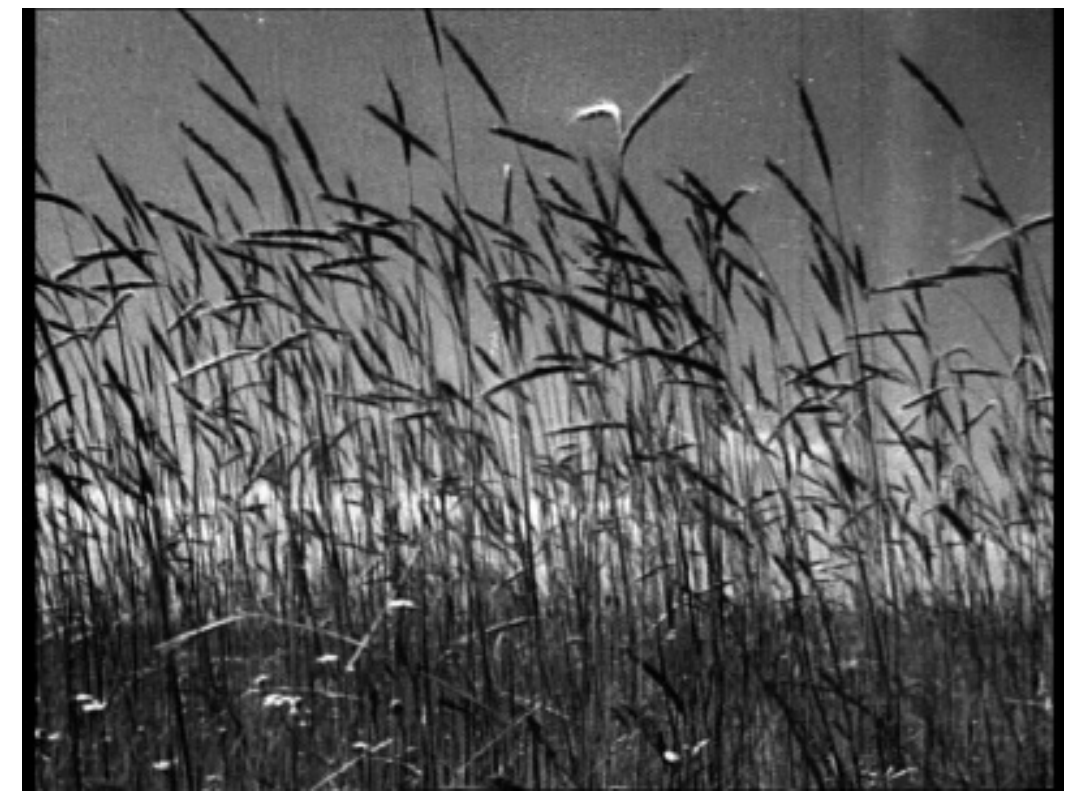

Fig. 5. Los yunteros de Extremadura (1936): espigas.

12 De la Fuente, 1936: 478. 


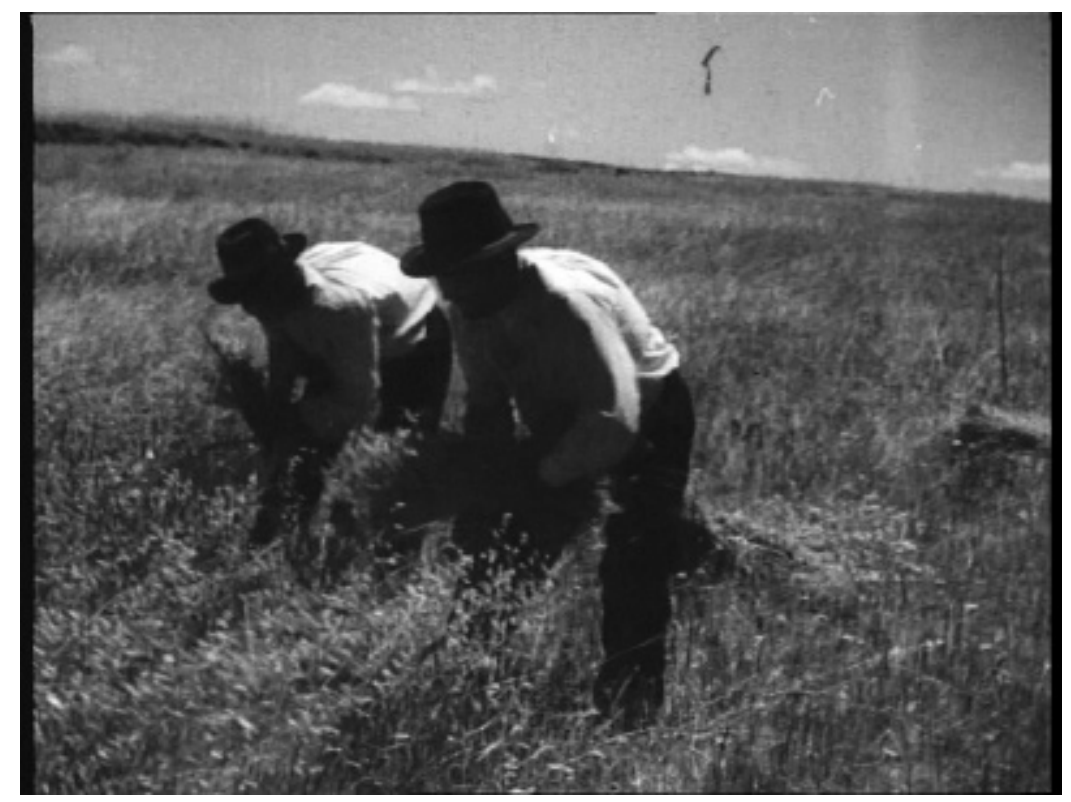

Fig. 6. Los yunteros de Extremadura (1936): haces de mies.

Trigo en España (1943), por ejemplo, donde no por casualidad las espigas están ya repletas de grano en unos campos tupidos de ellas ${ }^{14}$.

\section{“Dura es la vida del yuntero...". El hogar de las familias yunteras}

De súbito, el narrador proclama: "Dura es la vida del yuntero...". Palabras que abren la parte más extensa del documental, dedicada a narrar la vida del yuntero y centrada, sobre todo, en las viviendas que habita, de las que son visitadas hasta cinco de ellas, cada una más miserable que la anterior. Del primero de estos aposentos se muestra sólo el exterior, formado por una rudimentaria lona que, a modo de tienda de campaña, "sirve de alojamiento a los yunteros durante los meses de trabajo". Sin solución de continuidad, el filme pasa a describir otro habitáculo, en este caso su interior, las imágenes subrayando con planos detalle el mobiliario, elementos decorativos y vestuario descritos por el narrador: "Otros yunteros viven amontonados donde se pueden meter. En esta cocina guisan seis familias, y, como ajuar, las sartenes en una ventana; un cuerno para el aceite, en un rincón; los aperos, en otro, y, para completar la vivienda, un camastro para un matrimonio -la imagen muestra el camastro sobre un somier de piedra (fig. 7)-, y unos clavos para colgar su mísero vestuario -de ellos cuelgan prendas deformadas por el uso, imposible identificarlas-. Y como única ventilación, un agujero en la pared". Después del plano detalle correspondiente, en este caso recortando el agujero practicado en uno de los sucios muros de la habitación, prosigue el narrador: "En el mismo cuarto duerme otro matrimonio en esta cama, aquí una criatura - una panorámica va mostrando sucesivamente los distintos camastros- y un tercer matrimonio en la cama de al lado. Completa el cuadro un par de calcetines sucios y

14 Para estas cuestiones puede consultarse: POYATO, 2012. 
cepos para cazar las ratas que infestan el hogar. Un saco y un cajón forman la cama del niño, y, alumbrando tanta miseria, un viejo candil".

Son estas en efecto imágenes de una miseria desoladora que se localiza en esta vivienda infestada por las ratas y en cuyas habitaciones duermen hacinados varios matrimonios con sus hijos pequeños. Los sucios muros y las prendas tan gastadas como deformadas que de ellos cuelgan, ponen la guinda a este hogar cuya habitabilidad bordea los límites mismos de la dignidad humana. Por su parte, De la Fuente, a propósito de este mismo tema, apunta en el cuarto bloque de su Yuntero extremeño: "Y con las primeras horas del crepúsculo, el descanso en un ambiente cargado de impureza, en ese hogar al que faltan los elementos de higiene más indispensables y muchas veces junto a su yunta, compartiendo como alimento de ella y lecho de él, la misma paja... y a esperas que de nuevo amanezca"15. El documental detalla minuciosamente, como hemos comprobado, esos elementos que impiden una mínima higiene, llevando al límite algunos de ellos, exagerando otros, como por ejemplo el lecho, convertido en camastro de piedra, ni siquiera de paja (fig. 7). Las imágenes siguientes prosiguen con el inventario de hogares de yunteros para mostrar ahora el exterior de una vivienda en el que aparecen sucesivamente dos mujeres jóvenes junto a la puerta de entrada (fig. 8), y varias gallinas picoteando el suelo. Nada comenta la voz narradora de esta convivencia entre hombres y animales, pero sí sobre las mujeres jóvenes: "Apena pensar las tentaciones que asediarán a la gente joven para encontrar escape a tan dura vida", palabras desoladoras que inciden en la condena de la familia yuntera extremeña. Sin embargo, esas dos jóvenes de las imágenes aparecen sonrientes, y por ello completamente ajenas al asedio de esas tentaciones apuntadas por el narrador. Esta palpable falta de sincronía entre imagen y palabra, frecuente, como hemos señalado, en algunos pasajes del documental, demuestra una vez más las condiciones en que se hizo la película, filmando, se supone que precipitadamente, unos materiales que posteriormente no se ajustaban del todo al discurso proclamado por la voz narradora.

Invita este asunto a hacer una pequeña reflexión sobre la función del narrador en el documental, por cuanto su palabra no se limita a apoyar la imagen con explicaciones sobre lo que se ve en la pantalla, sino que bien por el contrario esa palabra se quiere enunciadora, limitándose entonces las imágenes a ilustrar, cuando pueden hacerlo, dada la patente falta de material disponible, esa palabra. En este caso anterior es claro que el material rodado se ajusta mal a la palabra, pero, dado que muy probablemente no fue posible hacer una nueva filmación, se optó por su incorporación. En otros segmentos posteriores del filme, esa misma falta de material disponible obligará a incorporar imágenes de textos ajenos, en una operación de found footage ciertamente interesante, como veremos más adelante.

Sea como sea, el narrador prosigue su discurso con el inventario y descripción de nuevas viviendas de los yunteros, las imágenes ilustrando sus palabras: "Otros viven en chozos, como los pastores de la Biblia. Terminada la tarea, desuncida la yunta, y encendido el fuego, empiezan los preparativos para pasar la noche. Lo primero, la sopa: pan, aceite, agua y, raras veces, algo más. Para dormir, un colchón sobre unas piedras; para sentarse, más piedras...” Más de lo mismo, como puede constatarse, si bien ahora se alude también a la rendida yunta, que, sin refugio alguno, ha de pasar la noche al raso, junto al carro, entre cuyos varales una arpillera le sirve de pesebre. Un hermoso contraluz del carro recortándose sobre un cielo con algunas nubes pone punto final a este segmento antes de que el narrador sentencie: "Y así pasa la noche el pobre yuntero, reponiendo su cuerpo cansado y mal nutrido". A las míseras condiciones de habitabilidad se une, pues, ahora la malnutrición del yuntero, aspectos que van a continuar protagonizando todavía los siguientes segmentos del filme.

15 De la Fuente, 1936: 477. 

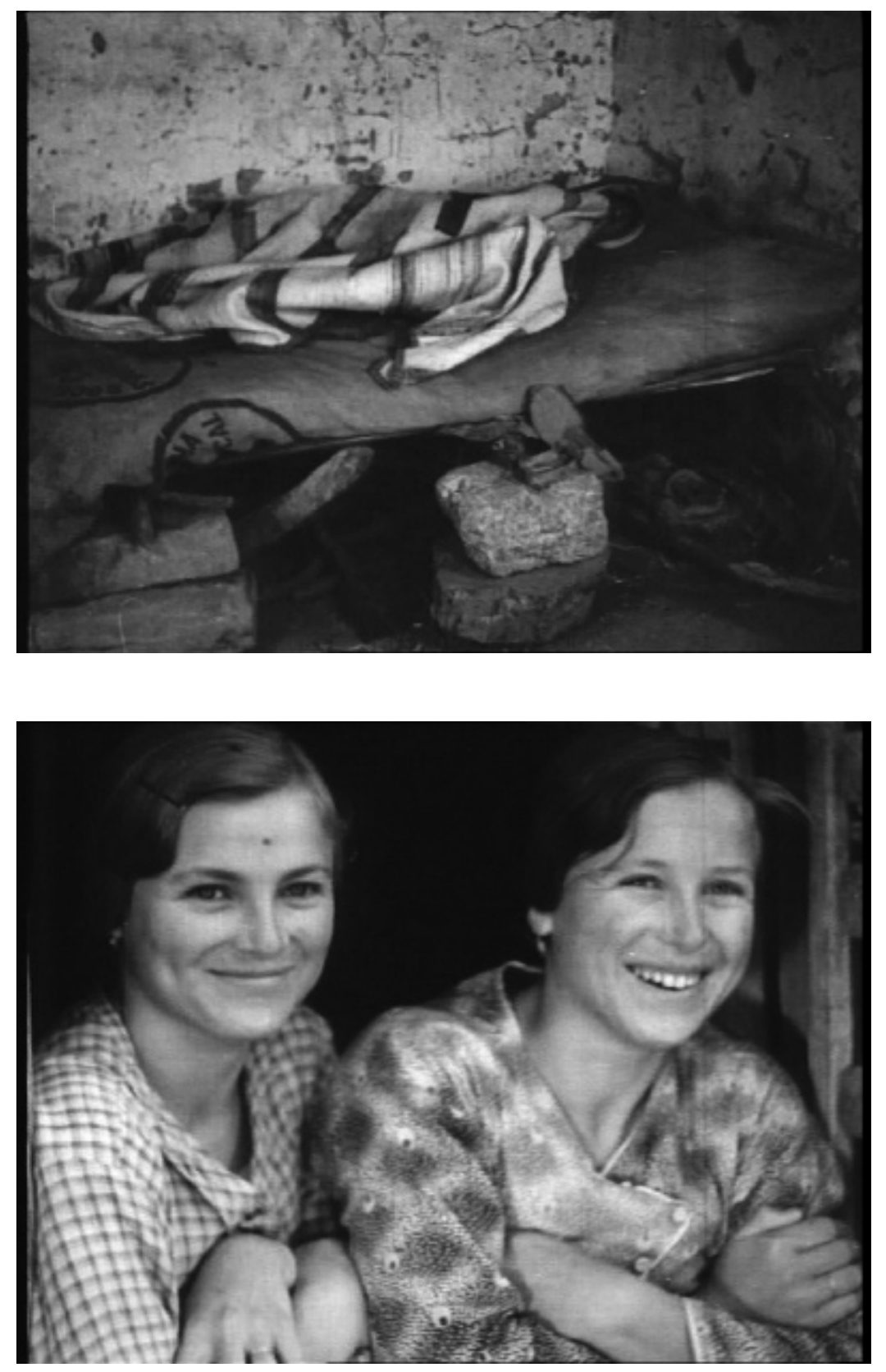

Fig. 7. Los yunteros de Extremadura (1936): lecho de piedra.
Fig. 8. Los yunteros de Extremadura (1936): jóvenes a la puerta de su casa.

\section{Las Hurdes/ Tierra sin pan como intertexto}

A partir de aquí, el documental de González de la Riva se aparta ya definitivamente del texto literario de De la Fuente para proseguir con la descripción de nuevos hogares yunteros, descripción que lo aproxima ahora a Las Hurdes/ Tierra sin pan. Sobre la imagen del exterior de otra casa de piedra y adobe, con mujeres y niños a la puerta, el narrador explica: "En esta casita

Arch. esp. arte, LXXXVII, 347, JULIO-SEPTIEMBRE 2014, 263-280

ISSN: 0004-0428, eISSN: 1988-8511, doi: 10.3989/aearte.2014.17 
tienen que dormir en el mismo cuarto dos matrimonios, los padres, la hija, el yerno y varios nietos. Una hoguera en el centro del cuarto sirve para guisar y, como salida de humos, un agujero en el techo". En esta ocasión es, pues, una misma habitación la que sirve de dormitorio y cocina a padres, hijos y nietos: hacinamiento $\mathrm{y}$ promiscuidad son, por tanto, los calificativos que mejor definen estas viviendas donde la privacidad, mucho menos la intimidad, no tienen cabida. Pero el colofón de estas descripciones lo pone el siguiente segmento: comienza este con el plano contrapicado de

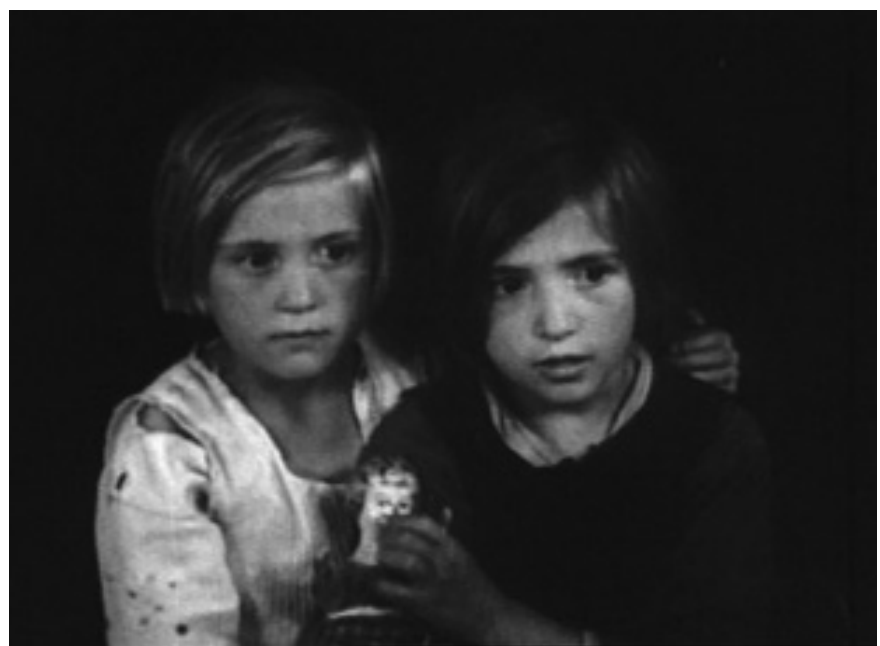

Fig. 9. Los yunteros de Extremadura (1936): niñas con hambre. unas casas en estado ruinoso, con las techumbres hundidas. Dice entonces el narrador: "Cuatro familias han de cobijarse bajo este tejado hundido...", añadiendo: "...y hoy son felices porque tienen para comer un cerdo muerto de la rabia que encontró la madre en un campo, arrostrando el peligro de infección por el placer de dejar saciada por una vez el hambre atrasada de sus hijos", palabras al hilo de las que aparece un plano detalle de los brazos levantados de una fila de niños implorando comida, y de dos niñas abrazadas (fig. 9) se diría que salidas de Las Hurdes de Buñuel, donde estas mismas niñas -entiéndase: dos niñas muy próximas en sus edades, vestuario y semblante- acudían hasta un arroyo para mojar en él un trozo de pan seco y poder así alimentarse.

Pero la vinculación de Los yunteros de Extremadura con el filme buñueliano, que habíamos empezado a establecer desde prácticamente el comienzo de este trabajo, va más allá de este apunte iconográfico anterior. Así, Las Hurdes/ Tierra sin pan pasa también revista a la vivienda y alimentación de un grupo humano extremeño, en este caso, los hurdanos. Y su narrador llama también la atención sobre el interior de uno de los hogares, concretamente sobre la cocina, donde "todos los utensilios son primitivos y escasos", y donde, dada la ausencia de chimenea y ventanas, "el humo sale por donde puede", todo ello ilustrado por dos series de planos: una del interior del hogar, que muestra a las mujeres prendiendo el fuego en la cocina, y otra del exterior, donde puede verse el intenso humo saliendo por todas las ranuras de las piedras de fachada y techo de la casa. Asimismo, Las Hurdes/ Tierra sin pan muestra el interior de otra vivienda donde la voz narradora insiste en proclamar que la habitan "el padre, el hijo y la nuera, y los dos nietos", habitantes que duermen, relata el narrador, "en una única habitación, donde excepcionalmente hay una cama". Una panorámica posterior muestra a todos los miembros de la familia, ya dormidos, en la misma y única cama, mientras el narrador concluye: "Los hurdanos se acuestan completamente vestidos en invierno; llevan la ropa hasta que se cae en jirones...".

Como vemos, son patentes las concomitancias de Los yunteros de Extremadura con el filme buñueliano, por mucho que este opte por mostrar los interiores de las viviendas, tanto la cocina como el dormitorio, con los componentes de la familia presentes, y aquel se limite -en lo que es una prueba más de la falta de material rodado- a describir visualmente esos mismos espacios sin las personas que los habitan. Ahora bien, el documental de González de la Riva llega, por lo que a la mostración/ descripción de la miseria y de la hambruna se refiere, más lejos que el de Buñuel -y por supuesto que el texto de De La Fuente, como ya decíamos-. Así, la situación desesperada 
de esa madre dando de comer a sus hijos la carne de un cerdo muerto por la rabia es algo propiamente devastador, que extralimita incluso las bárbaras costumbres de la España rural descritas por Regoyos y Verhaeven en su España negra (1924).

\section{¿Un documental de propaganda de la República?}

Cuando Los yunteros de Extremadura se hizo, muy poco o nada se sabía de la militancia política de González de la Riva, que él mismo proclamaría poco tiempo después cuando, tras ser detenido y posteriormente absuelto, en diciembre de 1936, acusado de pertenecer a la movilización de la Junta de Acción Popular (JAP) de la CEDA, se declaraba, en julio de 1937, identificado con "el Movimiento Salvador que dirige el Generalísimo, con alma y vida desde mucho antes del 18 de julio"16. Esta declaración arroja bastante luz para enmarcar un filme que, en vez de atender a la verdadera problemática de los yunteros en la fecha en que fue realizado, opta, como acabamos de ver, por registrar lo peor del modus vivendi de este campesinado extremeño. Por ello, al igual que Las Hurdes ${ }^{17}$, es esta una película claramente tendenciosa y políticamente militante que denuncia de manera implícita la dejadez de la República -que mantenía una situación tan lamentable- hacia la miserabilidad de las gentes extremeñas del campo, en este caso los yunteros -como en Las Hurdes eran los hurdanos-.

Por eso resulta cuanto menos sorprendente que Los yunteros de Extremadura fuera una de las películas recabadas en 1937 por la Delegación de Propaganda de la República en París, según relata Juan Vicens, la persona que entonces estaba al frente de dicha Delegación, en un amplio informe dirigido al gobierno en Valencia sobre las actividades realizadas por su Departamento entre marzo y noviembre de $1937^{18}$. Señala Vicens en este documento que para la Delegación de Propaganda era prioritario recoger cuantos filmes fueran susceptibles de servir a los fines propagandísticos de la República, lamentándose a este propósito de la falta de material disponible, pues de entre la numerosa producción cinematográfica realizada en España con el apoyo económico del Estado, durante el primer año de guerra, sólo habían podido hacer acopio de cinco películas que reunieran esas condiciones de propaganda. Pues bien, una de estas películas era Los yunteros, producida por el Ministerio de Agricultura, a la que se añadían Defensa del campo y 18 de julio, producidas ambas por la Alianza de Intelectuales Antifascistas; y España por Europa y Nuestros prisioneros, producidas por el Comisariado General de Guerra.

Nuestro análisis anterior demuestra, sin embargo, que el documental de los yunteros, por mucho que se contara entre ese grupo de cinco filmes oficiales destinados a servir a la propaganda, operaba, más bien, en sentido contrario pues, a diferencia de los otros cuatro, que realzaban la España de la Segunda República, amalgamando el proceso de modernización con los rasgos arcaicos, y donde se pretendía mostrar a España como una democracia asediada que luchaba contra el fascismo, Los yunteros de Extremadura se mostraba especialmente crítico con la República del Frente Popular.

Mas, por otro lado, de esas cinco películas subvencionadas con dinero del Estado, sólo una de ellas, 18 de julio, según proseguía relatando Vicens en su informe, estaba preparada para los públicos extranjeros, al disponer de versiones en francés e inglés. Esta circunstancia llevaría a

16 Carta del Marqués de Villa Alcázar al Presidente de la Comisión de Agricultura y Trabajo Agrícola, 16 de julio de 1937, Archivo del Instituto de Reforma Agraria, Ministerio de Agricultura, Madrid, Estado, expediente personal del Marqués de Villa Alcázar.

17 Gubern, Hammond, 2009: 186-188.

18 Informe de Juan Vicens al Gobierno, s/f., Archivo de la Administración General del Estado, Alcalá de Henares (AGA), Estado, caja 54/11065, carpeta 6324.

Arch. esp. arte, LXXXVII, 347, JULIO-SEPTIEMBRE 2014, 263-280

ISSN: 0004-0428, eISSN: 1988-8511, doi: 10.3989/aearte.2014.17 
que las otras cuatro películas, entre ellas Los yunteros, no pudieran ser distribuidas comercialmente $^{19}$, limitándose muy probablemente su difusión al préstamo gratuito a organizaciones y comités amigos, según cabe inferir de lo recogido en el informe. Difusión esta que por lo demás iba a verse extraordinariamente restringida cuando instrucciones llegadas desde España abogaban únicamente por la distribución comercial de los filmes con el fin de obtener la mayor cantidad posible de divisas y poder adquirir así material fotográfico, tan escaso en España, según recoge la carta enviada por Juan Vicens al embajador español en París, el día 2 de octubre de $1937^{20}$. Estos pormenores permiten suponer que Los yunteros fue, a pesar de haber sido seleccionado, un filme muy poco visto en Francia, lo que desde el punto de vista ideológico beneficiaría sin duda a la República.

Tierra sin pan, la versión sonora de Las Hurdes, producida en Francia, sí sería, sin embargo, utilizada por el Departamento para la propaganda, aun cuando la misma no hubiera sido exhibida en las sesiones programadas por el Pabellón Español de la Exposición Internacional. A este propósito, Gubern ha señalado cómo a pesar de la coda didáctica añadida, con la que se intentaba denunciar la agresividad bélica fascista ${ }^{21}$, Tierra sin pan seguía ofreciendo la misma imagen negra y primitiva de la versión primera de Las Hurdes, y, con ella, manifestando su denuncia, a partir de las consignas dictadas por la Comintern, de la República hacia esa región miserable ${ }^{22}$. Pues bien, Los yunteros de Extremadura, seleccionada igualmente para su exhibición con fines propagandísticos, es tan crítica con la República como Las Hurdes, si bien en este caso el filme sigue no las consignas comunistas autorizadas por la Comintern, sino las conservadoras nacionalistas proclamadas por la CEDA, como quedaría demostrado poco después, cuando, como anticipábamos más arriba, González de la Riva, en escrito dirigido al Presidente de la Comisión de Agricultura y Trabajo Agrícola, manifestaba su identificación con el Alzamiento Nacional del Generalísimo. He aquí, por tanto, dos filmes igualmente críticos con la República si bien desde posiciones contrarias del espectro político e ideológico.

\section{La causa de tanta miseria. El destino del yuntero}

Una vez registrada por las imágenes la situación de penuria y hambruna de la familia yuntera, Los yunteros de Extremadura se interroga por las causas de tan lamentables condiciones de vida: “¿Por qué tanta miseria en la antes próspera Extremadura?”. Sobre las imágenes de castillos y casas señoriales, con sus escudos en piedra, de ciudades como Trujillo y Plasencia, esa misma voz anterior, después de advertir cómo "antaño había colocación en los palacios y dehesas extremeñas, mientras que hoy no", se ocupa de razonar las causas: "la alteración secular de mejora del arbolado, que ha derivado en la explotación del pastoreo, esos finísimos pastos extremeños en los que el viento escribe su poema sin fin, produce una escasez de jornales que lleva a vivir al pueblo, ahogado por la falta de tierra, en la mayor miseria”. Una serie de imágenes fijas de la dehesa extremeña ilustra este discurso hasta que, de pronto, el mismo hace una extrapolación del

\footnotetext{
19 Lo que se compensaría con títulos como Guerra en el campo, Galicia, y 9 noticiarios -los tres en francés-, así como con las producciones francesas Attentat contre Madrid, Terre sans pain, y Espagne 36.

${ }^{20}$ Carta de Juan Vicens al embajador español en París, 2 de octubre de 1937, Archivo de la Administración General del Estado, Alcalá de Henares (AGA), caja 54/11065, carpeta 6324.

${ }^{21}$ Fue precisamente esta coda que modificó el mensaje político de lo que hasta entonces había sido una obra antirrepublicana, lo que convirtió a Tierra sin pan en escopetazo introductorio en la campaña de propaganda pro-republicana para recordar a la opinión pública francesa, británica y norteamericana los funestos efectos de la política de No Intervención de sus respectivos gobiernos. En GUBERN, HAMMOND, 2009: 295.

22 Gubern, Hammond, 2009: 323-324.
} 
campo a la ciudad. Y así, ayudándose de un fondo de imágenes de ciudades cacereñas, entre las que puede adivinarse Trujillo, sus plazas vacías de gente, algunas de sus edificaciones derruidas, el narrador insiste en el estado ruinoso de la ciudad extremeña, erigida aquí en representante de la ciudad española. Pues es de ello de lo que se trata, de denunciar una situación crítica en la España de 1936 por parte de un filme en este sentido claramente tendencioso y políticamente militante donde la miseria y la ruina son los grandes aliados de las ciudades españolas y sus habitantes. Los yunteros de Extremadura se reafirma así, según ya adelantábamos, como un filme de denuncia, de crítica a los poderes públicos de la República que habían dado origen a esta situación.

Después de dar cuenta del estado ruinoso de los pueblos y ciudades extremeñas, la película vuelve sobre el yuntero, quien, como consecuencia de la situación vivida, se ve obligado -comenta el narrador- "a emigrar al terruño donde puede labrar, y al final de la senda, viejo ya, gastado, abandonada la lucha, solo espera el refugio del asilo, si es que para entonces tienen sitio para él”. Dos imágenes de escala muy corta se intercalan en este discurso último: la primera de ellas es el retrato de un yuntero anciano, su cara marcada por los años y por una poblada barba, vistiendo una aparatosa capa de paño (fig. 10); y la del cartel que luce a la puerta del asilo, donde puede leerse: "Casa-Asilo de las Hermanitas de los ancianos desamparados". Dos imágenes que exhiben su procedencia externa al documental, en especial la primera de ellas, por cuanto el gesto alegre, incluso risueño, del yuntero desmiente, como ya destacábamos en otras imágenes anteriores, las palabras del narrador referidas a un desamparo que sentencia la segunda de las imágenes, ese cartel que no por casualidad cierra el filme y donde se escribe el destino que, después de una vida llena de miserias, aguarda al yuntero.

Aun cuando se trate de un segmento externo, la incorporación de las imágenes del anciano yuntero al tejido del documental permite fijar en todo caso las cualidades fotográficas, cualidades sobre las que, por cierto, se ancla una diferencia con respecto a Las Hurdes/ Tierra sin pan. Pues si esa imagen del yuntero (fig. 10) se descubre visualmente emparentada al pictorialismo fotográfico español de las primeras décadas del siglo XX, así en sus efectos rugosos y aterciopelados que suavizan las texturas, las imágenes buñuelianas se caracterizan porque en ellas los hurdanos aparecen tan mineralizados, tal es la intensidad de la transferencia matérica operada en la fotografía, como la propia realidad que habitan ${ }^{23}$. Por eso, el par Piedra/ Paño del que, a propósito de la fotografía pictorialista de Ortiz Echagüe, hablara Ortega ${ }^{24}$, y que protagoniza las imágenes que, como la anterior, forjan la iconografía del yuntero, en Las Hurdes deviene solo Piedra, materia minera ${ }^{25}$. Precisamente, esta conjugación del par Piedra/ Paño suaviza considerablemente en la imagen del documental de González de la Riva el feísmo descarnado que protagoniza las imágenes que el filme de Buñuel ofrece de los hurdanos.

Por lo demás, y como no podía ser de otro modo de acuerdo con la línea ideológica que preside Los yunteros de Extremadura, también su final acentúa el perfil dramático del yuntero. A diferencia de Yuntero extremeño, el texto de De la Fuente que hemos tomado como motivo de comparación a lo largo del análisis, que concluye proclamando que el yuntero "Hoy ya tiene tierra", por mucho que sea una tierra todavía "insuficiente y no segura", e invitando a "ir directos a una solución integral" para evitar que el problema resurja ${ }^{26}$, el documental del Marqués de

${ }^{23}$ A lo que sin duda contribuye el vestuario: si los yunteros recubren su cuerpo con un atuendo de pana negra que pardea, por mucho que con parches mal disimulados y manchas extensas, como dice De la Fuente; los hurdanos llevan la ropa con jirones, como apuntaba el narrador buñueliano.

24 ORTEGa y GaSSET, 1930: 8-15.

25 Este tema aparece desarrollado en: PoYATO, 2010: 60-67.

26 De la Fuente, 1936: 478.

Arch. esp. arte, LXXXVII, 347, JULIO-SEPTIEMBRE 2014, 263-280

ISSN: 0004-0428, eISSN: 1988-8511, doi: 10.3989/aearte.2014.17 


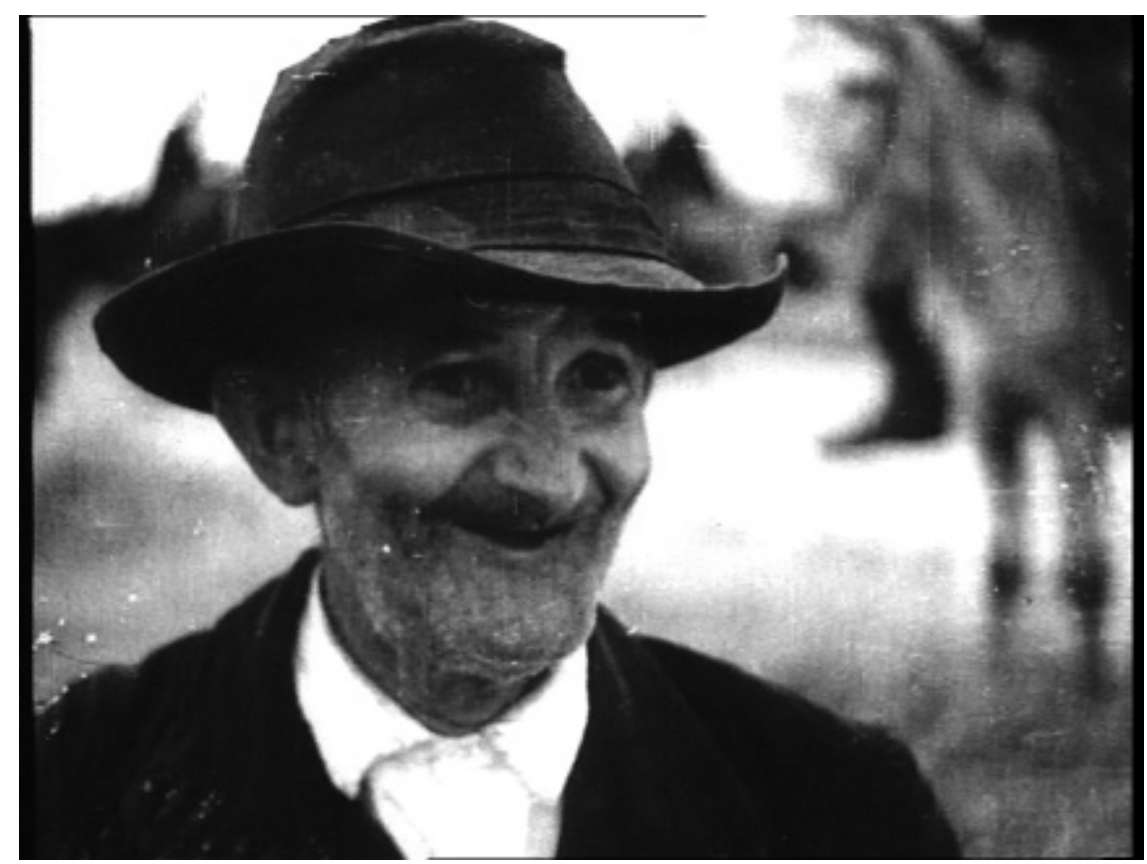

Fig. 10. Los yunteros de Extremadura (1936): yuntero anciano.

Villa-Alcázar convoca al yuntero, primero a la emigración y desarraigo que ella conlleva, y luego, en el retorno, al desamparo del asilo.

\section{BIBLIOGRAFÍA}

Camarero Rioja, Fernando, Catálogo de Documentales Cinematográficos Agrarios, 1895 / 1981, Madrid, Ministerio de Medio Ambiente y Medio Rural y Marino, 2010.

De la Fuente, Felipe, "Yuntero extremeño", Boletín del Instituto de Reforma Agraria, n. ${ }^{\circ}$ 47, 1936, pp. 475478.

Espinosa Maestre, Francisco, La primavera del Frente Popular, Barcelona, Crítica, 2007.

Gubern, Román, y Hammond, Paul, Los años rojos de Buñuel, Madrid, Cátedra, 2009.

Malefakis, Edward, Reforma agraria y revolución campesina en la España del siglo XX, Barcelona, Ariel, 1976.

Ortega y Gasset, José, "Para una ciencia del traje popular", en Tipos y trajes de España, Madrid, Espasa Calpe, 1930, pp. 8-15.

Poyato, Pedro, "La aldea maldita (F. Rey, 1930), una película rural regeneracionista", en Gómez Gómez, Agustín, y Poyato, Pedro (coords.), Profundidad de Campo, Girona, Luces de Gálibo, 2010, pp. 60-67.

Poyato, Pedro, "Las charlas cinematográficas del Marqués de Villa-Alcázar: documental científico e ideología en el primer franquismo", en Actas del IV Congreso Latina de Comunicación Social, La Laguna, diciembre de 2012. [Disponible en: http://www.revistalatinacs.org/12SLCS/2012_actas.html].

Riesco Roche, Sergio, "La cuestión yuntera en Extremadura durante la II República", Historia Social, n. ${ }^{\circ}$ 65, 2009, pp. 41-64.

Fecha de recepción: 23-IX-2013

Fecha de aceptación: 12-II-2014

Arch. esp. arte, LXXXVII, 347, JULIO-SEPTIEMBRE 2014, 263-280 ISSN: 0004-0428, eISSN: 1988-8511, doi: 10.3989/aearte.2014.17 